\title{
ANGULAR POSITIONING ACCURACY OF ROTARY TABLE AND REPEATABILITY OF FIVE-AXIS MACHINING CENTRE DMU 65 MONOBLOCK
}

\author{
Jerzy Józwik' ${ }^{1}$ Marek Czwarnowski² \\ 1 Department of Production Engineering, Mechanical Engineering Faculty, Lublin University of Technology, \\ Nadbystrzycka Str. 36, 20-618 Lublin, Poland, e-mail: j.jozwik@pollub.pl \\ 2 The State School of Higher Education in Chelm, Institute of Technical Sciences and Aviation, 22-100 Chelm, \\ Center for the Study of Engineering, Depułtycze Królewskie 55, e-mail: mczwarnowski@pwsz.chelm.pl
}

Received: 2015.09.21

Accepted: 2015.11.14

Published: 2015.12.04

\begin{abstract}
The study aims to evaluate angular positioning accuracy and repeatability of DMU 65 monoBLOCK numerically controlled machine tool. The measurements were carried out with XL-80 Laser Interferometer with XR20-W attachment. The measurements were conducted according to the standard PN-ISO230-2. Test methodology and measurement results analysis are presented in a form of figures and tables. The final part presents conclusions from the analysis.
\end{abstract}

Keywords: positioning, diagnostics, accuracy, $\mathrm{CNC}$ machine tool, laser interferometer

\section{INTRODUCTION}

Simultaneously with advances in subtractive machining technologies the dimensional and shape accuracy requirements for the components produced with $\mathrm{CNC}$ machine tools increase. The quality of finished products depends on, inter alia, positioning accuracy and repeatability of numerically controlled axes, linear and angular errors (and their measurements), axes alignment (assembly errors), or backlash in the servo drive (operational errors). Each inaccuracy of the machine is reflected in the final quality of the product [1-4].

In recent years, five-axis machine tools have become widely popular in production processes. This is because of growing capabilities of such machine tools in performing increasingly complex motions and in machining complicated shapes. Most of such machines are used in aircraft and automotive industries, where five-axis machine tools enable producing components of complicated geometry, such as: turbine blades, generators, geometrically intricate car or aircraft elements, etc. Realisation of complex machining motions requires multi-axis $\mathrm{CNC}$ machine tools with not only linear axes but with rotational axes as well.
The most widespread realisation of a rotary axis in CNC machines, without which it would be impossible to produce the mentioned components, are rotary or swivel rotary tables, frequently included in the machine tool as a complementation of a linear axis. Usually the rotary axes are parallel to selected linear axes of the machine tool; however, in certain machine tools the rotary axis is situated at a $45^{\circ}$ angle to one of the linear axes of the machine. Rotary axes in machining centres do not have to be essentially connected with the table. In certain machine tools the design solutions enable the spindle axis to realise motions independently of the square table of the machine [4-6].

While the accuracy of linear axes is relatively uncomplicated in control and compensation, it is only since quite recently that rotary axis errors can be equally effectively measured and compensated. This has been made possible by developments in diagnostic methods and tools dedicated for these applications. The study methods connected with rotary axis error measurement in machining centres can be divided into two categories. The first one is the method of rotary axis positioning error measurement, while the second category includes methods of spatial orientation 
of a rotary axis with relation to linear axes, determination of actual rotary axis and the evaluation of stability axis centre [7-12].

One of the most popular methods of rotary axis positioning error measurement is the method employing a laser interferometer with an attachment enabling measurement of rotary axes. This method is applied according to standard ISO 2302 [13]. The interferometer attachment performs motions following the changes of rotary axis angular position in the opposite direction to the rotary motion of the table. The motion is set to maintain the measuring angle between the laser beam and the rotary table. The error is effectively the difference between the target position, determined by the laser system, and the actual angular position of the tested axis of a machine. This method enables verification of axis positioning accuracy, which is of great importance for component machining. The analysis of error characteristics enables verification of the sources of these errors (in the majority of cases an imprecise rotary angle encoder or its improper mounting [12]). The precision of the interferometric method is $\pm 0.5 "[14-15]$.

\section{TEST CONDITIONS AND METHODOLOGY}

The conducted tests aimed to measure the angular positioning accuracy and repeatability of $\mathrm{C}$ axis of a vertical machining centre CMU 65 monoBLOCK (Fig. 1). The tested machine tool is

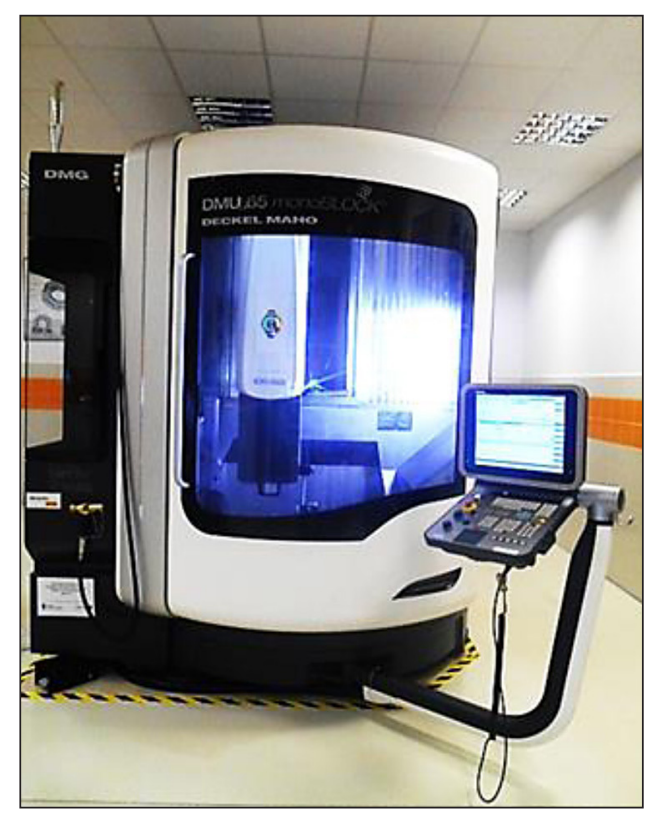

Fig. 1. Five-axis machining centre DMU 65 monoBLOCK used in piece production and in didactic process. The measurements were carried out according to international standard PN-ISO 230-2, describing norms for determination of geometric accuracy of machine tools for the machining of metals. The measurements were performed with XL-80 Laser Interferometer (Fig. 2) equipped with a rotary axis calibrator attachment XR20-W (Fig. 3). The measurements provided data on errors critical to the dimensional and shape accuracy of produced components.

The diagnostic and measurement process is preceded by a series of setting and regulation procedures. At the first stage of these setting and regulation procedures, the XR20-W calibrator is located precisely on the rotary axis of the table (Fig. 4). Next, the angular retroreflector is mounted on the magnetic base. XR20-W calibrator is wirelessly connected with the software via Bluetooth interface.

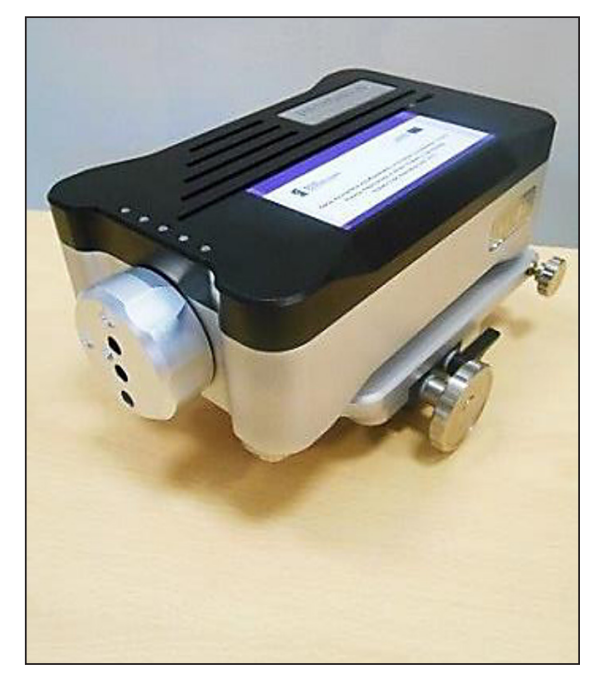

Fig. 2. Laser Interferometer XL-80 (Renishaw)

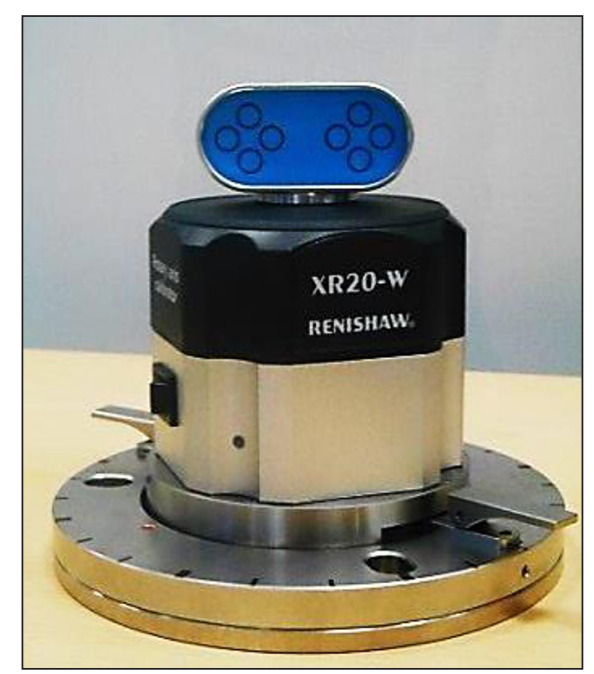

Fig. 3. Rotary axis calibrator XR20-W (Renishaw) 


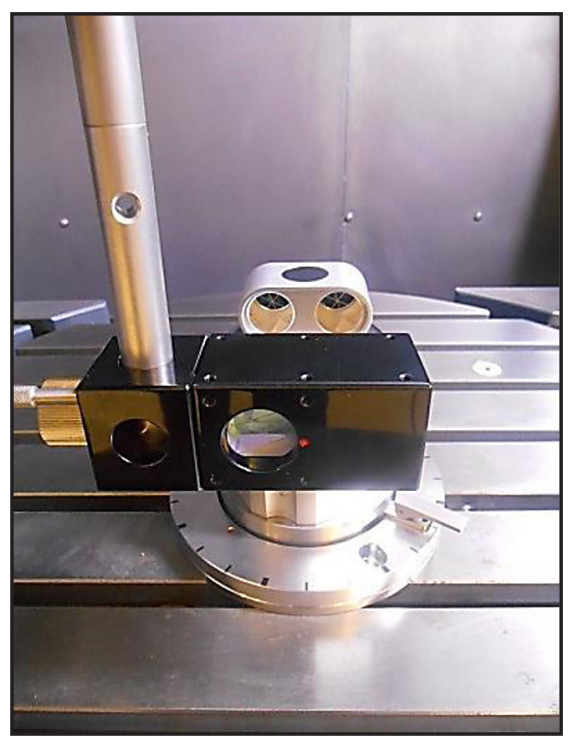

Fig. 4. Setting XR20-W calibrator and mounting angular retroreflector

In preparation for the $\mathrm{C}$ axis positioning accuracy measurement the machine tool table was programmed to perform a rotary motion at $\alpha=30^{\circ}$ steps at the full rotation scope $360^{\circ}$ (Fig. 5). A $4 \mathrm{sec}$ interval was at every discreet measurement position (at every $30^{\circ}$ ), during which time the angular position measurement was recorded and captured. After a full revolution, the table moved in the opposite direction $\left(30^{\circ}\right.$ step size, $4 \mathrm{sec}$ interval) until the initial target position was reached. Each test included three measuring cycles. In order to determine the measurement repeatability the tests were repeated 6 times in identical conditions.

\section{TEST RESULTS}

Measurement and analysis of test results was conducted with XCal-View 2.1. Obtained measurement data is shown in a form of tables

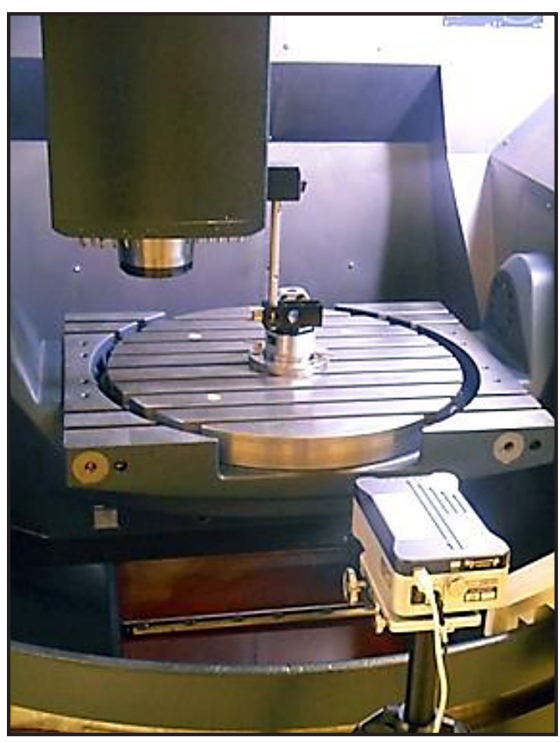

Fig. 5. Preparation for and measurement of positioning errors

and figures. The computer programme generated curves showing deviations as a function of angular position of the table, and their mean values in each repetition ( 3 cycles) are shown in Figures 6 and 7 . They show a typical graphical representation of the unconverted measurement data (before any analytical formatting), according to the standard ISO-230-2.

Table 1 and Table 2 show detailed statistical data and result analysis for three repetitions of $360^{\circ}$ in set directions (CW and CCW) (as examples of results obtained in tests 1 and 2).

Table 3 and Table 4 show selected errors measured in tests. All measurement results are presented with a cyclometric function expressed in arcsecs. The combination of XR20-W and laser interferometer allows measurement accuracy within \pm 1 arcsec, which corresponds to a displacement of less than $5 \mathrm{~mm}$ at a distance of $1 \mathrm{~m}$ ).

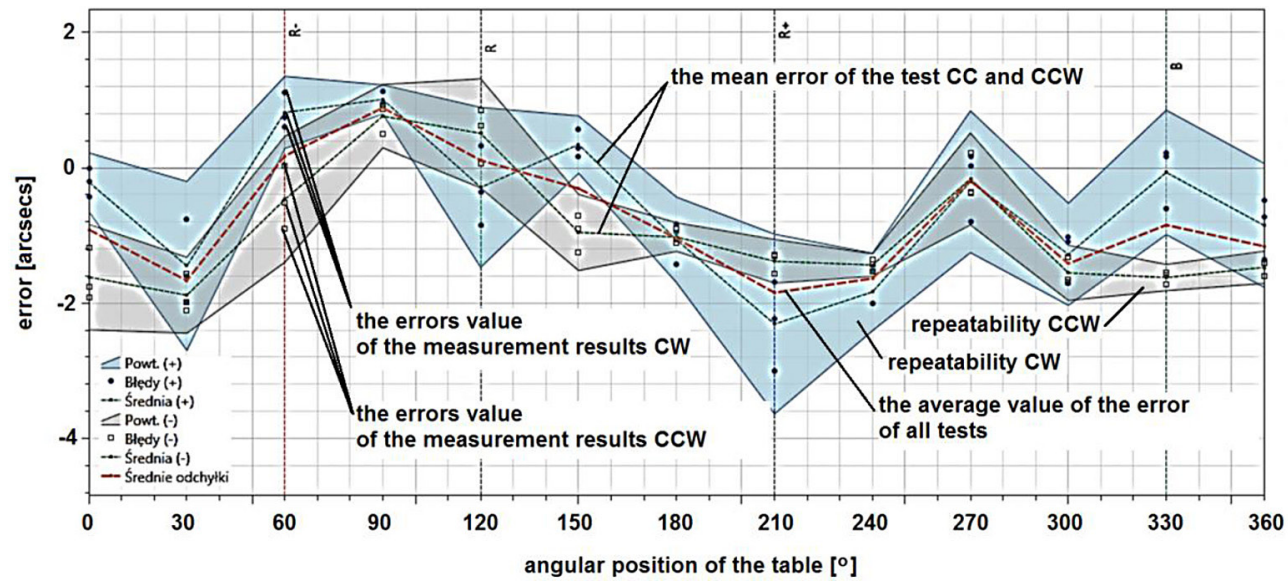

Fig. 6. Positioning and repeatability errors (test 1) 


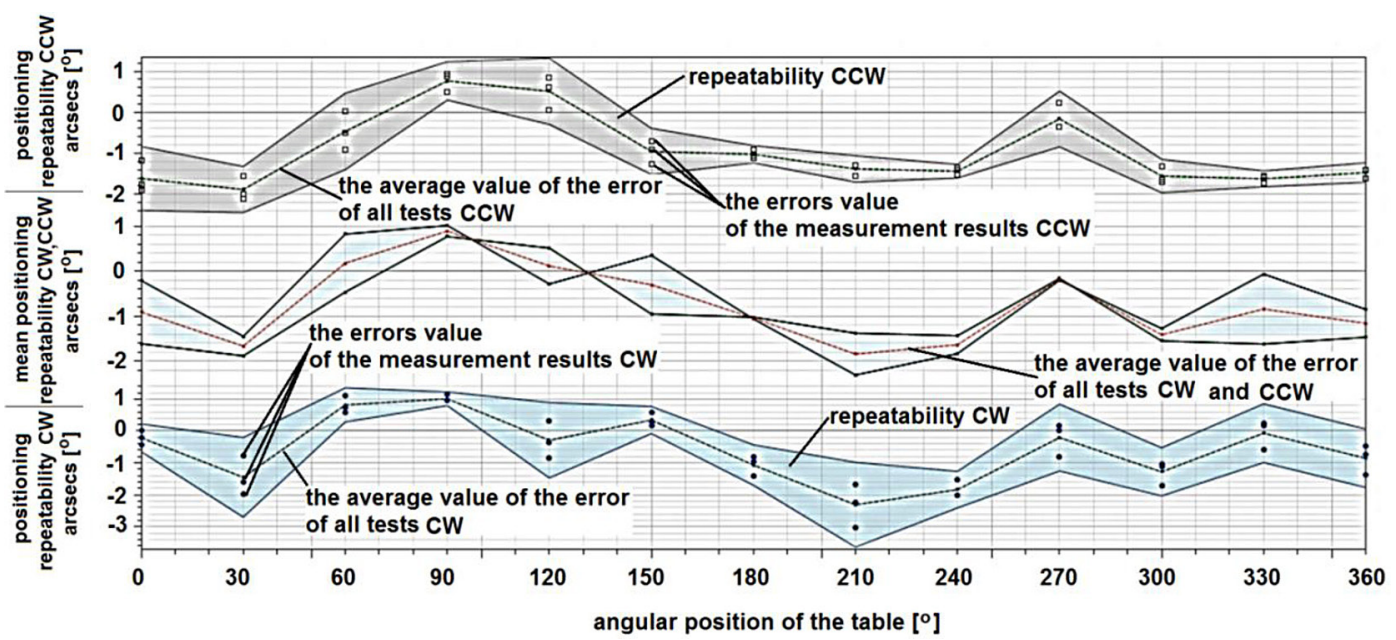

Fig. 7. Positioning and repeatability errors and deviations with rotation direction (CW; $\mathrm{CCW}$ ) of $\mathrm{C}$ axis (test 1$)$

Table 1. Measurement results statistics (test 1)

\begin{tabular}{|c|c|c|c|c|c|c|c|c|c|c|c|c|c|c|c|c|c|c|c|c|c|c|c|c|c|c|}
\hline \multirow{3}{*}{$\begin{array}{r}\text { Numer punktu docelowego (i) } \\
\text { Polożenie ( () } \\
\text { Kierunek }\end{array}$} & \multirow{2}{*}{\multicolumn{2}{|c|}{1}} & \multirow{2}{*}{\multicolumn{2}{|c|}{2}} & \multirow{2}{*}{\multicolumn{2}{|c|}{3}} & \multicolumn{2}{|c|}{4} & \multirow{2}{*}{\multicolumn{2}{|c|}{ 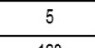 }} & \multirow{2}{*}{\multicolumn{2}{|c|}{ MI }} & \multirow{2}{*}{\multicolumn{2}{|c|}{$m$}} & \multirow{2}{*}{\multicolumn{2}{|c|}{210}} & \multirow{2}{*}{\multicolumn{2}{|c|}{ 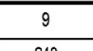 }} & \multirow{2}{*}{\multicolumn{2}{|c|}{10}} & \multirow{2}{*}{\multicolumn{2}{|c|}{11}} & \multirow{2}{*}{\multicolumn{2}{|c|}{12}} & \multirow{2}{*}{\multicolumn{2}{|c|}{ 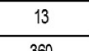 }} \\
\hline & & & & & & & \multicolumn{2}{|c|}{90} & & 120 & & & 180 & & & & & & & 270 & & & & & & \\
\hline & - & + & - & + & - & + & - & + & - & + & - & + & - & + & - & + & - & + & $\cdot$ & + & $\cdot$ & + & & + & & + \\
\hline \multirow{3}{*}{ Pobizenie Odshylk Xii] } & $-1,2$ & 0,0 & $-2,1$ & $-0,8$ & 0,0 & 0,7 & 0,9 & 1,1 & 0,8 & 0,3 & $-0,7$ & 0,2 & $-1,1$ & $-0,9$ & $-1,3$ & $-1,7$ & $-1,4$ & $-2,0$ & $-0,4$ & $-0,2$ & $-1,7$ & $-1,1$ & $-1,5$ & 0,2 & $-1,6$ & $-0,5$ \\
\hline & $-1,9$ & $-0,2$ & $-1,6$ & $-2,0$ & $-0,9$ & 1,1 & 0,5 & 0.9 & 0,1 & $-0,4$ & $-0,9$ & 0,6 & $-1,1$ & $-0,8$ & $-1,3$ & $-2,2$ & $-1,5$ & $-1,5$ & $-0,4$ & 0.0 & $-1,3$ & $-1,0$ & $-1,6$ & 0,2 & $-1,4$ & $-0,7$ \\
\hline & $-1,8$ & $-0,4$ & $-2,0$ & $-1,6$ & $-0,5$ & 0,6 & 0,9 & 0,9 & 0,6 & $-0,8$ & $-1,3$ & 0,3 & $-0,9$ & $-1,4$ & $-1,6$ & $-3,0$ & $-1,4$ & $-2,0$ & 0,2 & $-0,8$ & $-1,7$ & $-1,7$ & $-1,7$ & $-0,6$ & $-1,4$ & $-1,4$ \\
\hline Śrectne odchyki kiernnkowe & $-1,6$ & $-0,2$ & $-1,9$ & $-1,5$ & $-0,5$ & 0,8 & 0,8 & 1,0 & 0,5 & $-0,3$ & $-1,0$ & 0,3 & $-1,0$ & $-1,1$ & $-1,4$ & $-2,3$ & $-1,4$ & $-1,8$ & $-0,2$ & $-0,2$ & $-1,6$ & $-1,3$ & $-1,6$ & $-0,1$ & $-1,5$ & $-0,9$ \\
\hline Standardow a nepew ność Si & 0,4 & 0,2 & 0,3 & 0,6 & 0,5 & 0,3 & 0,2 & 0,1 & 0,4 & 0,6 & 0,3 & 0,2 & 0,1 & 0,3 & 0,2 & 0,7 & 0,1 & 0,3 & 0,3 & 0,5 & 0,2 & 0,4 & 0,1 & 0,5 & 0,1 & 0,5 \\
\hline $2 \times \mathrm{Si}$ & 0,8 & 0,4 & 0,6 & 1,2 & 0,9 & 0,5 & 0,5 & 0,2 & 0,8 & 1,2 & 0,6 & 0,4 & 0,2 & 0,6 & 0,3 & 1,3 & 0,2 & 0,6 & 0,7 & 1,0 & 0,4 & 0,8 & 0,2 & 0,9 & 0.2 & 0,9 \\
\hline $4 \times 5$ & 1,6 & 0,9 & 1,1 & 2,5 & 1,9 & 1,1 & 0,9 & 0,4 & 1,6 & 2,4 & 1,1 & 0,8 & 0,4 & 1,3 & 0,6 & 2,7 & 0,3 & 1,1 & 1,4 & 2,1 & 0,8 & 1,5 & 0,4 & 1,8 & 0,5 & 1,8 \\
\hline Średnia - 25i & $-2,4$ & $-0,6$ & $-2,4$ & $-2,7$ & $-1,4$ & 0,3 & 0,3 & 0,8 & $-0,3$ & $-1,5$ & $-1,5$ & $-0,1$ & $-1,2$ & $-1,7$ & $-1,7$ & $-3,6$ & $-1,6$ & $-2,4$ & $-0,8$ & $-1,3$ & $-2,0$ & $-2,0$ & $-1,8$ & $-1,0$ & $-1,7$ & $-1,8$ \\
\hline Średnia + 2Si & $-0,8$ & 0,2 & $-1,3$ & $-0,2$ & 0,5 & 1,4 & 1,2 & 1,2 & 1,3 & 0,9 & $-0,4$ & 0,8 & $-0,8$ & $-0,4$ & $-1,1$ & $-1,0$ & $-1,3$ & $-1,3$ & 0,5 & 0,8 & $-1,1$ & $-0,5$ & $-1,4$ & 0,9 & $-1,2$ & 0,1 \\
\hline Zw rotny B & 1. & 4 & & 4 & & & & & & 8 & & 3 & 0 & & & & & & 0, & 0 & 0,3 & 3 & 1 & 6 & & \\
\hline vtanzalność dw ukerunkow a Ri & 2 & 6 & 2 & 5 & 2 & & & & & 8 & & 3 & 1 & 3 & & & 1 & & 2 & 1 & 1, & 5 & 2 & & & \\
\hline Średnie odchyk & -0 &, 9 & & & 0 & & 0 & & & 1 & & & & & & & -1 & & -0 & 2 & -1, & & & 8 & & \\
\hline
\end{tabular}

Table 2. Measurement results statistics (test 2)

\begin{tabular}{|c|c|c|c|c|c|c|c|c|c|c|c|c|c|c|c|c|c|c|c|c|c|c|c|c|c|c|}
\hline \multirow{3}{*}{$\begin{array}{r}\text { Numer punktu docelowego (i) } \\
\text { Polożenie (i) } \\
\text { Kierunek } \\
\end{array}$} & \multirow{2}{*}{\multicolumn{2}{|c|}{1}} & \multirow{2}{*}{\multicolumn{2}{|c|}{2}} & \multirow{2}{*}{\multicolumn{2}{|c|}{60}} & \multicolumn{2}{|c|}{4} & \multicolumn{2}{|c|}{5} & & & \multicolumn{2}{|c|}{8} & \multicolumn{2}{|c|}{9} & \multicolumn{2}{|c|}{10} & \multicolumn{2}{|c|}{11} & \multicolumn{2}{|c|}{12} & \multicolumn{2}{|c|}{13} \\
\hline & & & & & & & \multicolumn{2}{|c|}{90} & \multicolumn{2}{|c|}{120} & \multicolumn{2}{|c|}{150} & \multicolumn{2}{|c|}{180} & \multicolumn{2}{|c|}{210} & \multicolumn{2}{|c|}{240} & \multicolumn{2}{|c|}{270} & \multicolumn{2}{|c|}{300} & \multicolumn{2}{|c|}{330} & \multicolumn{2}{|c|}{360} \\
\hline & - & + & - & + & - & + & - & + & - & + & - & + & - & + & & + & - & + & - & + & - & + & & + & - & + \\
\hline \multirow{3}{*}{ Fobzenie Odchylik Xi] } & $-1,4$ & 0,0 & $-1,2$ & $-0,6$ & $-0,3$ & 1,4 & 0,2 & 1,2 & 0,0 & $-1,2$ & $-1,7$ & $-0,4$ & $-2,4$ & $-1,5$ & $-1,6$ & $-2,2$ & $-1,9$ & $-1,9$ & $-0,9$ & 0,1 & $-1,1$ & $-0,9$ & $-1,9$ & 0,4 & $-1,4$ & $-0,5$ \\
\hline & $-1,9$ & 0,1 & $-1,2$ & $-1,5$ & $-0,1$ & 0,4 & 0,3 & 0,2 & $-0,3$ & $-1,5$ & $-1,6$ & $-0,8$ & $-2,0$ & $-1,7$ & $-1,3$ & $-2,5$ & $-1,7$ & $-2,3$ & $-0,7$ & $-0,7$ & $-1,2$ & $-1,2$ & $-2,0$ & $-0,4$ & $-1,2$ & $-0,7$ \\
\hline & $-1,5$ & $-0,5$ & $-1,6$ & $-1,2$ & $-0,6$ & 0,1 & 0,2 & 0,2 & $-0,5$ & $-2,0$ & $-2,3$ & $-1,2$ & $-1,9$ & $-2,4$ & $-1,9$ & $-3,4$ & $-1,9$ & $-2,7$ & $-0,8$ & $-0,7$ & $-1,4$ & $-1,2$ & $-2,1$ & $-0,8$ & $-1,3$ & $-0,5$ \\
\hline Śreçnie odchyki kerunkowe & $-1,6$ & $-0,1$ & $-1,3$ & $-1,1$ & $-0,3$ & 0,6 & 0,3 & 0,5 & $-0,3$ & $-1,6$ & $-1,9$ & $-0,8$ & $-2,1$ & $-1,9$ & $-1,6$ & $-2,7$ & $-1,8$ & $-2,3$ & $-0,8$ & $-0,4$ & $-1,2$ & $-1,1$ & $-2,0$ & $-0,3$ & $-1,3$ & $-0,6$ \\
\hline Standardow a niepew nośćc Si & 0,3 & 0,3 & 0,2 & 0,5 & 0,2 & 0,7 & 0,0 & 0,5 & 0,3 & 0,4 & 0,4 & 0,4 & 0,3 & 0,4 & 0,3 & 0,6 & 0,1 & 0,4 & 0,1 & 0,5 & 0,2 & 0,2 & 0,1 & 0,6 & 0,1 & 0,1 \\
\hline $2 \times \mathrm{si}$ & 0,6 & 0,6 & 0,5 & 0,9 & 0,5 & 1,4 & 0,1 & 1,1 & 0,5 & 0,8 & 0,7 & 0,9 & 0,5 & 0,8 & 0,6 & 1,2 & 0,2 & 0,8 & 0,2 & 0,9 & 3,0 & 0,3 & 0,2 & 1,2 & 0,2 & 1,0 \\
\hline $4 \times$ Si & 1,2 & 1,3 & 0,9 & 1,8 & 1,0 & 2,8 & 0,2 & 2,2 & 1,1 & 1,6 & 1,5 & 1,8 & 1,1 & 1,7 & 1,2 & 2,4 & 0,3 & 1,7 & 0,4 & 1,8 & 0,6 & 0,7 & 0,4 & 2,4 & 0,4 & 0,3 \\
\hline Średnia-2Si & $-2,2$ & $-0,8$ & $-1,8$ & $-2,1$ & $-0,8$ & $-0,8$ & 0,2 & $-0,6$ & $-0,8$ & $-2,4$ & $-2,6$ & $-1,7$ & $-2,6$ & $-2,7$ & $-2,2$ & $-3,9$ & $-2,0$ & $-3,1$ & $-1,0$ & $-1,3$ & $-1,5$ & $-1,4$ & $-2,2$ & $-1,5$ & $-1,5$ & $-0,7$ \\
\hline Śrectna + 2Si & 1,0 & 0,5 & 0,8 & 0,2 & 0,2 & 2,0 & 0,3 & 1,6 & 0,3 & $-0,7$ & $-1,1$ & 0,1 & $-1,6$ & $-1,0$ & $-1,0$ & $-1,5$ & $-1,7$ & $-1,4$ & $-0,6$ & 0,5 & $-0,9$ & $-0,7$ & $-1,8$ & 0,9 & $-1,1$ & $-0,4$ \\
\hline Zw rotny Bi & 1 & 5 & & 2 & & & & & -1 & & & 1 & 0 & 2 & -1 & & & & 0, & & & 1 & 1,7 & & & 7 \\
\hline ow taralhośćc dw ukierunkow a Ri & 2, & 7 & & 8 & & & & & 2 & & & 7 & 1 & 7 & & & & & 1, & & & 8 & 3,1 & & 1 & 1 \\
\hline Średnie odchyki & -0 & 19 & & 2 & & & & & -0 & & &, 3 & -2 & & & & & & -0 & & & 1 & -1, & 1 & & 0,9 \\
\hline
\end{tabular}

Table 3. Measurement results analysis (test 1)

\begin{tabular}{|l|c|c|c|}
\hline Nazwa & $(+)$ arcsecs & $(-)$ arcsecs & (Bidir) arcsecs \\
\hline Dokładność [A] & 5,0 & 3,8 & 5,0 \\
\hline Powtarzalność [R] & 2,7 & 1,9 & 2,8 \\
\hline Odchyłka systemowa [ [日] & 3,3 & 2,6 & 3,3 \\
\hline
\end{tabular}

\begin{tabular}{|l|c|}
\hline Nazwa & Wartość (arcsecs) \\
\hline Zw rotny [B] & 1,6 \\
\hline Średni błąd zw rotny & 0,4 \\
\hline Odchylenie średnie [M] & 2,7 \\
\hline
\end{tabular}

Table 4. Measurement results analysis (test 2)

\begin{tabular}{|l|c|c|c|}
\hline Nazwa & $(+)$ arcsecs & $(-)$ arcsecs & (Bidir) arcsecs \\
\hline Dokładność [A] & 5,9 & 3,0 & 5,9 \\
\hline Pow tarzalność [R] & 2,8 & 1,5 & 3,1 \\
\hline Odchyłka systemow a [E] & 3,3 & 2,4 & 3,3 \\
\hline
\end{tabular}

\begin{tabular}{|l|c|}
\hline Nazwa & Wartość (arcsecs) \\
\hline Zw rotny [B] & 1,7 \\
\hline Średni błąd zw rotny & 0,3 \\
\hline Odchylenie średnie $[\mathrm{M}]$ & 2,5 \\
\hline
\end{tabular}


Figure 8 shows results of all conducted tests. The presented characteristics indicate that angular positioning error $[\mathrm{A}]$ of $\mathrm{C}$ axis is very small, between $5 \div 5.9$ arcsecs (deviation $\mathrm{s}=0.468$ arcsecs). The remaining measured error values are even lower. Positioning repeatability $[R]$ of the $\mathrm{C}$ axis and systematic deviation [E] are approximately 3 arcsecs. Error return [B] was registered at $1.6 \div 1.7$ arcsecs whereas average return error
$0.3 \div 0.4$ arcsecs. Average deviation [M] values were recorded within $2.5 \div 2.7$ arcsecs.

Figure 9. Shows average values of positioning error $[\mathrm{A}]$ in all conducted measurements (6 tests) both in positive and negative direction, as a function of angular positions of the table (at $\alpha=30^{\circ}$ ).

Figure 10 shows a summary of average values of positioning accuracy, errors and deviations obtained in all tests and repetitions, in

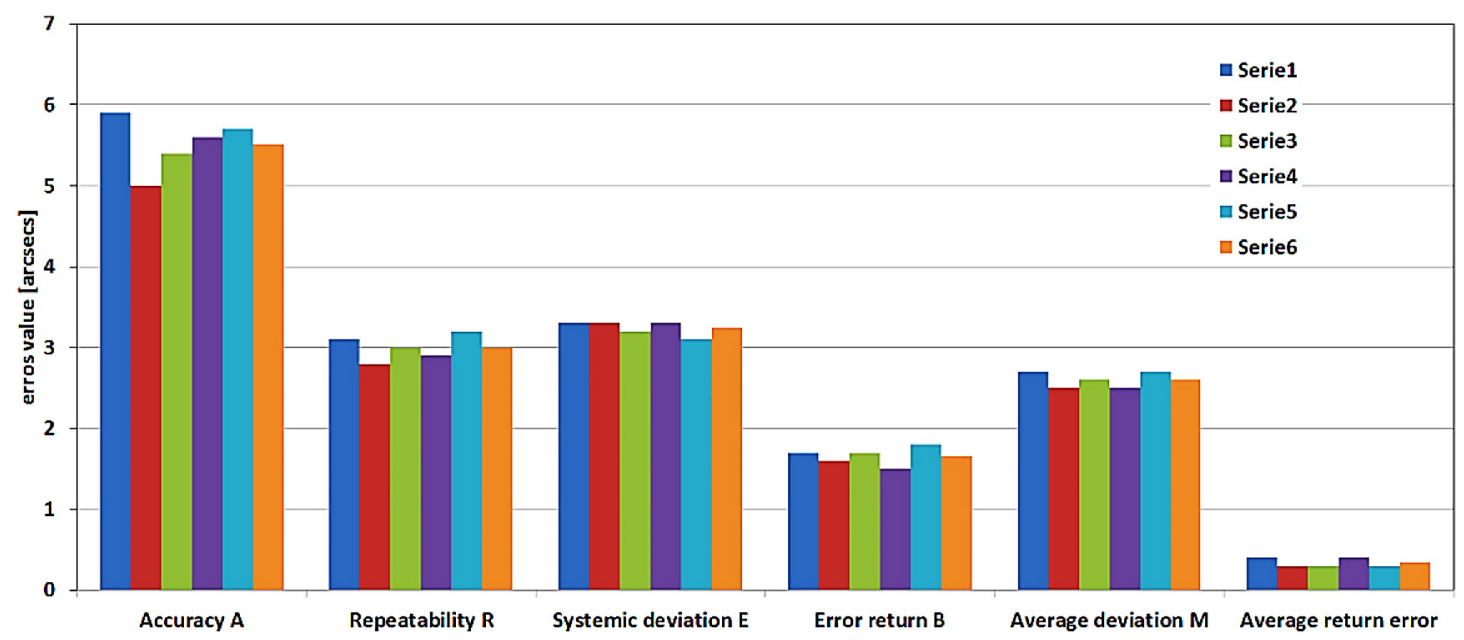

Fig. 8. Comparative analysis of $\mathrm{C}$ axis positioning errors and deviations at particular measuring series
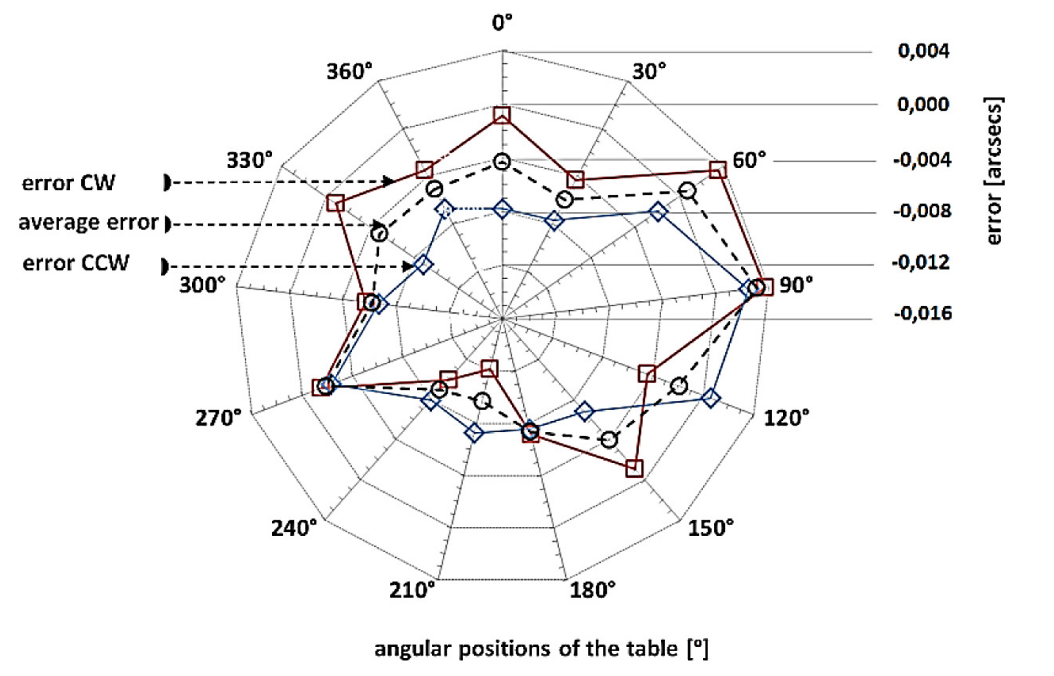

Fig. 9. Average positioning errors $[\mathrm{A}]$ in 6 repetitions, in $\mathrm{CW}$ and $\mathrm{CCW}$ directions

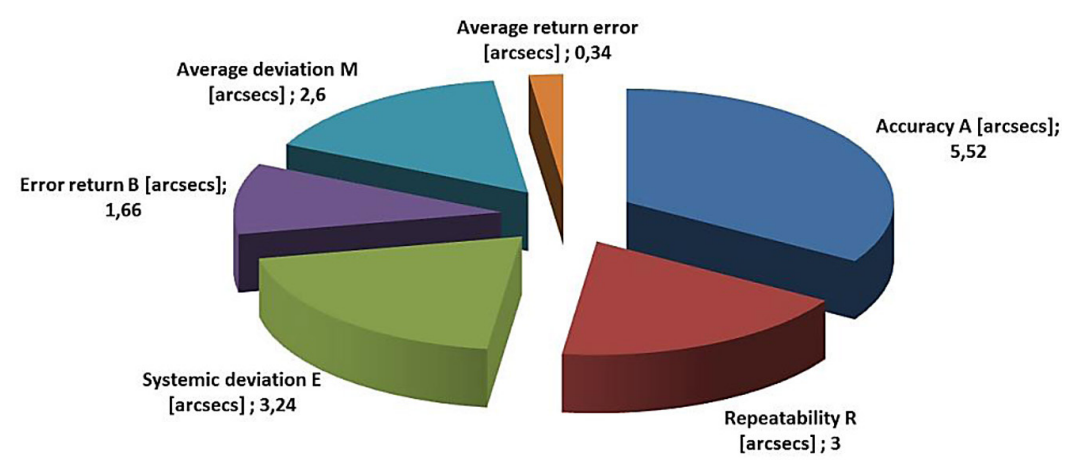

Fig. 10. Average positioning deviations in all tests and repetitions, in each series 
each series. Figure 10 clearly indicates that the highest error value recorded was in the case of positioning accuracy [A], and its average value was 5.52 arcsecs. Average repeatability [R] of rotary $\mathrm{C}$ axis positioning is equal to 3 arcsecs, and average systematic deviation [E] amounts to 3.24 arcsecs. Return error [B] amounted to 1.66 arcsecs, whereas average return error was 0.34 arcsecs. Average deviation [M] value was 2.6 arcsecs. Subsequent accuracy and repeatability of angular positioning and other angular deviations of the analysed axis of the machine tool will allow designing a prognostic model allowing prediction of geometric accuracy of the machine tool.

\section{CONCLUSIONS}

Measurement and diagnostic methods for numerically controlled machine tools based on light wave interferometry are currently a leading solution in CNC machine tools diagnostics. Noncontact measurements provide superior accuracy in determining machine tool elements in motion, both linear and angular. In addition, the laser system offers excellent measurement accuracy.

The majority of modern CNC machine tools enable linear and angular error compensation. If repeatable, angular position errors can be compensated. Removing or minimising errors leads to improving the technical condition of machines, which is furthermore reflected in machining quality. This is obtained with simple, universal, user-friendly and high-precision laser interferometry measurement systems. An example of such a system is the XL-80 Laser Interferometer with XR20-W calibration attachment. It allows the estimation of linear and angular geometric errors.

The conducted tests for the analysed $\mathrm{C}$ axis of CNC machine tool show that maximum angular positioning deviation was obtained for the angular position $210^{\circ}$. These are, however, within the tolerance given in PN-ISO230-2. Angular positioning error of the rotary axis of the analysed machine tool did not exceed 6 arcsecs, and repeatability is equal to 3 arcsecs. According to ISO standards the errors measured in the analysed machine tool do not exceed the acceptable values. Based on obtained angular positioning error values the tested machine's condition can be described as very good. The obvious reason for the condition of the machine is that it has not been used in factory conditions, but served as a didactic tool and was used for piece production.

The test results presented in this paper were recorded in the database of the analysed machine history. They will serve as a base for building a prognostic model of geometric accuracy of machine tools. Building such a model, and its further application in factory conditions, will allow proper planning of the machine tool operation process (maintenance and repairs), whereas in a direct manner, it will allow reduce or compensate measured errors. The model will also serve as a classifier for determining the suitability of the analysed tool for production of components of particular dimensional and shape requirements.

\section{REFERENCES}

1. Bringmann B.: Improving geometric calibration methods for multi-axes machining centers by examining error interdependencies effects. Fortschritt-Berichte VDI, 2/664, Dusseldorf 2007.

2. Bringmann B., Knapp W.: Model-based 'Chasethe-Ball' calibration of a 5-Axes machining center. Annals of the CIRP 55(1), 2006, 531-534.

3. Honczarenko J., Kwaśniewicz J.: Nowe systemy pomiarowe do sprawdzania dokładności obrabiarek CNC. Mechanik, 12, 2008, 1012-1016.

4. Jastrzębski R., Krajewski G.: Metody diagnostyki błędów precyzyjnych stołów obrotowych w obrabiarkach CNC. XIV Krajowa i V Międzynarodowa Konferencja Naukowo-Techniczna „Metrologia w Technikach Wytwarzania”, 11-14 września, Pułtusk 2011.

5. Józwik J., Kuric I., Sága M., Lonkwic P.: Diagnostics of CNC machine tools in manufacturing process with laser interferometer technology. Manufacturing Technology, 14(1), 2014, 23-30.

6. Józwik J., Kuric I., Grozav S., Ceclan V. (): Calibration of 5 axis CNC machine tool with 3D quickSET measurement system. Academic Journal of Manufacturing Engineering, 12 (1), 2014.

7. Józwik, J., Krajewski, G., Jacniacka, E., Pieśko, P., Włodarczyk, M.: Prognozowanie dokładności obrabiarki CNC na podstawie szeregu czasowego. Cz. 1. Wybrane urządzenia diagnostyczne obrabiarek CNC. 10th International Conference „Automation in Production Planning and Manufacturing" Published by Scientific and Technical Society at the University of Zilina, 4-6 May, Slovakia 2009.

8. Józwik J., Krajewski G., Jacniacka E., Pieśko P., Włodarczyk M.: Prognozowanie dokładności 
obrabiarki $\mathrm{CNC}$ na podstawie szeregu czasowego. cz. 2. Prognozowanie odchyłki okrągłości i prostopadłości osi obrabiarki CNC. 10th International Conference „Automation in Production Planning and Manufacturing“. Published by Scientific and Technical Society at the University of Zilina, 4-6 May, Slovakia 2009.

9. Józwik J., Krajewski G., Pieśko P.: Evaluation of QC10 Ballbar diagnostics method for CNC machine. Eksploatacja i Niezawodność, No. 1, 2010.

10. Józwik J., Kuric I. Semotiuk L.: Laser interferometer diagnostics of CNC machine tools. Communications, 3A, 2014, 167-173.

11. Miko E., Maj P.: Badanie dokładności pozycjonowania pionowego centrum obróbkowego. PAK, 56(1), 2012, 63-65.
12. PN-ISO 230-2:2001 Warunki badania centrów obróbkowych, Część 2: Dokładność i powtarzalność pozycjonowania w osiach liniowych i obrotowych.

13. Szafarczyk M., Chrzanowski J.: Nowa koncepcja sprawdzania dokładności maszyn NC. In: Automation, „Automatyzacja-Nowości i Perspektywy”, Warszawa 2005, 405-413.

14. Weikert S, Knapp W.: R-test: A new device for accuracy measurements on five axis machine tools. Annals of the CIRP, 53(1), 2004, 429-432.

15. Woźniak A., Byszewski M., Jankowski M., Krajewski G.: Spatial characteristics of the triggering force of touch probes for CNC machine tools. In: $2^{\text {nd }}$ International Conference on Virtual Machining Process Technology, McMaster University, Hamilton, Ontario, Canada, May 13-17, 2013. 